\title{
PENGARUH SARANA BELAJAR TERHADAP PRESTASI BELAJAR ILMU PENGETAHUAN SOSIAL DI SEKOLAH DASAR
}

\author{
Wina Dwi Puspitasari \\ winadwi49@ymail.com
}

\begin{abstract}
ABSTRAK
Pendidikan Ilmu Pengetahuan Sosial (IPS) sebagai salah satu program pendidikan di lingkungan sekolah dihadapkan kepada tantangan untuk mempersiapkan manusia Indonesia seutuhnya yang mampu berkiprah dalam kehidupan masyarakat modern. Tujuan umum pendidikan IPS di sekolah adalah tercapainya prestasi belajar peserta didik, yang dalam hal ini adalah menciptakan warga negara yang mampu mengerti masyarakatnya dan mampu berpartisipasi aktif di dalam proses perubahan dan pengembangan masyarakat. Dalam rangka mencapai hal tersebut, salah satunya harus didukung dengan sarana belajar serta lingkungan belajar yang memadai. Tujuan yang ingin dicapai dalam penelitian ini adalah untuk mengetahui seberapa besar pengaruh sarana belajar terhadap prestasi belajar siswa pada mata pelajaran IPS di kelas V SDN Tarikolot II Kabupaten Majalengka.

Penelitian ini menggunakan explanatory survey method, yaitu suatu metode penelitian yang dimaksudkan untuk menemukan dan mengembangkan teori, sehingga hasil atau produk penelitiannya dapat menjelaskan kenapa atau mengapa terjadinya sesuatu gejala atau kenyataan sosial tertentu. Populasi pada penelitian ini adalah seluruh siswa kelas V SDN Tarikolot II Kabupaten Majalengka yang berjumlah 17 orang siswa. Sedangkan teknik analisis data penelitian yang digunakan adalah teknik korelasi product moment dan teknik pengujian hipotesis yang digunakan melalui uji t.

Berdasarkan hasil penelitian, dapat diambil kesimpulan bahwa terdapat pengaruh sarana belajar terhadap prestasi belajar siswa pada mata pelajaran IPS di kelas V SDN Tarikolot II. Adapuan besarnya korelasi yang dihasilkan sebesar 0,51. Nilai tersebut terletak antara 0,40 0,599 atau berkategori sedang. Sedangkan, berdasarkan pengujian hipotesis, didapat nilai $t$ hitung pada taraf nyata 0,05 berada di luar batas interval $t_{\text {tabel }}\left(\mathrm{t}_{\text {hitung }}>t_{\text {tabel }}=2,82>1,74\right.$ atau $\left.-t_{\text {hitung }}<-t_{\text {tabel }}=-2,82<-1,74\right)$. Dengan demikian, hipotesis yang dikemukakan di awal yaitu ada pengaruh sarana belajar terhadap prestasi belajar siswa pada mata pelajaran IPS di kelas V SDN Tarikolot I Kabupaten Majalengka dapat diterima dan telah terbukti kebenarannya.

Mengacu pada hasil penelitian, penulis mengajukan beberapa saran; 1) bagi sekolah, sarana belajar merupakan salah satu faktor penentu keberhasilan dalam proses pembelajaran, maka pihak sekolah harus menyediakan sarana dan prasaran belajar yang memadai yang disesuaikan dengan kemampuan yang ada, 2) bagi guru, para guru senantiasa lebih memaksimalkan penggunaan media maupun alat-alat pembelajaran, 3) bagi siswa, diharapkan mempunyai motivasi yang tinggi dalam mengikuti kegiatan pembelajaran. Selain itu, agar senantiasa menjaga dan jangan merusak semua sarana dan prasaran pembelajaran yang ada di sekolah.
\end{abstract}

Kata Kunci : Sarana Belajar, Prestasi Belajar Siswa

\footnotetext{
${ }^{1}$ Penulis adalah dosen tetap Prodi PGSD Fakultas Pendidikan Dasar dan Menengah Universitas Majalengka
} 


\section{Pendahuluan}

Pendidikan memegang peranan sangat penting dalam menciptakan siswa yang berprestasi dan memiliki kualitas Sumber daya manusia (SDM) yang berkualitas dan berdaya guna bagi masyarakat banyak nantinya. Peningkatan sumber daya manusia merupakan langkah terpenting yang harus di tempuh dalam dunia pendidikan. Sumber daya manusia yang berkualitas dan berpotensi dalam arti yang luas yang diciptakan oleh dunia pendidikan akan membentuk sumber daya manusia tersebut dalam rangka menyikapi perubahan global yang akan mempengaruhi tata kehidupan bermasyarakat, berbangsa dan bernegara.

Berhasil atau tidaknya dunia pendidikan menciptakan sumber daya manusia yang berkualitas dan berpotensi salah satunya dipengaruhi oleh mutu pendidikan melalui pembinaan dan pengarahan anak didik menjadi manusia yang berakhlak mulia dan mampu berkembang dengan baik sesuai dengan kemampuannya serta bakat yang ada pada diri anak tersebut. Dalam mewujudkan tingkat pendidikan yang berkualitas, program belajar sangatlah berpengaruh terhadap prestasi belajar seseorang. Pendidikan yang berkualitas akan mampu menghasilkan siswa yang berprestasi tinggi dan sebagai sumber daya manusia yang berkualitas tinggi pula. Untuk mencapai peningkatan mutu pendidikan tersebut salah satunya harus didukung dengan fasilitas belajar yang memadai dan lingkungan belajar yang efektif.

Sarana belajar sangat berpengaruh terhadap perkembangan belajar anak seperti yang dikatakan oleh Djamarah dan Zain (2008: 208) bahwa "siapapun akan sependapat bahwa sarana dan prasarana belajar ikut menentukan keberhasilan seseorang". Orang yang belajar tanpa dibantu fasilitas tidak jarang mendapat hambatan dalam menyelesaikan kegiatan belajar karenanya, fasilitas tidak bisa diabaikan dalam masalah belajar. Fasilitas dan perabot yang dimaksud tentu saja berhubungan dengan masalah materil berupa kertas, pensil, buku catatan, meja dan kursi belajar.

Sarana belajar yang dimaksud juga merupakan alat-alat yang dipergunakan siswa dalam membantu proses belajarnya seperti ruangan belajar, alat-alat pelajaran, penerangan dan suasana tempat belajar. Fasilitas belajar mempunyai pengaruh terhadap prestasi belajar siswa, semakin lengkap fasilitas belajar yang dimiliki maka siswa dapat belajar lebih baik, mempermudah, mempercepat dan memperdalam proses belajar mandiri siswa. Dengan proses belajar mandiri yang efektif maka prestasi belajar akan diperoleh dengan maksimal. Untuk itu, fasilitas belajar sangat diperlukan untuk mencapai prestasi belajar siswa. dan sebaliknya jika fasilitas belajar tidak lengkap dapat mengganggu proses belajar, sehingga berdampak pada prestasi belajar yang diperoleh siswa (Djamarah dan Zain, 2009: 209).

Selain faktor fasilitas belajar yang memadai, prestasi belajar siswa juga dipengaruhi oleh faktor yang bersumber dari lingkungan belajar yang efektif, yaitu lingkungan belajar yang produktif, dimana sebuah lingkungan belajar yang dirancang atau dibangun untuk membantu siswa meningkatkan produktifitas belajar mereka, sehingga proses belajar mengajar tercapai sesuai dengan yang diharapkan. Di dalam sebuah lingkungan belajar yang efektif, siswa akan bisa menjadi lebih produktif, hal ini di gambarkan dengan kemudahan para siswa dalam berpikir, berkreasi juga mampu belajar secara aktif dikarenakan lingkungan belajar yang sangat mendukung sehingga timbul ketertarikan dan kenyamanan pada saat proses belajar mengajar berlangsung. Terutama orang tua yang merupakan salah satu faktor pendidikan, lembaga pertama dalam kehidupan anak, tempat anak belajar dan menyatakan diri sebagai makhluk sosial.

Sebagaimana diketahui, bahwa keberhasilan pendidikan seseorang sangat dipengaruhi oleh beberapa faktor, antara lain bakat anak, kecerdasan anak, kegiatan belajar di sekolah dan lingkungan yang 
mempengaruhi anak baik dari lingkungan keluarga, sekolah atau masyarakat. Lingkungan memberikan pengaruh yang sangat besar terhadap pembentukan berbagai sifat, sikap, perasaan dan pemikiran anak, sehingga diharapkan pada nantinya lingkungan tersebut dapat menciptakan atau memberikan pendidikan yang baik terhadap perkembangan anak (Djamarah dan Zain, 2008: 208).

Selain pendidikan formal yang dilakukan di sekolah, pendidikan juga perlu diberikan sejak dini. Pendidikan ini dilakukan dalam keluarga, karena keluarga merupakan tempat belajar yang utama. Pendidikan keluarga dikatakan pendidikan yang utama karena di dalam keluarga anak mulai belajar pengetahuan dan kecerdasannya. Keluarga mempunyai tanggung jawab yang besar terhadap pendidikan anak, karena orang tua harus membina anaknya agar dapat menjadi manusia yang utuh.

Prestasi belajar membutuhkan partisipasi dari berbagai pihak dan tidak hanya bergantung pada guru atau siswa itu sendiri, akan tetapi juga dipengaruhi oleh sarana prasarana belajar dan faktor keluarga. Perhatian orang tua sangat dibutuhkan oleh siswa demi motivasi belajar agar dapat mendapatkan prestasi yang baik, begitu juga dengan keadaan rumah seperti fasilitas belajar, sarana dan prasarana belajar yang mendukung di rumah.

Berdasarkan hasil observasi peneliti di SDN Tarikolot II Kabupaten Majalengka, kondisi prasarana belajar siswa di sekolah masih banyak kekurangan, sehingga kurang mendukung untuk kegiatan proses belajar mengajar dan berdampak kepada kualitas belajar anak. Kemudian Prestasi belajar siswa di SDN Tarikolot II Kabupaten Majalengka pada mata pelajaran Ilmu Pengetahuan Sosial masih tergolong rendah hal ini terbukti dari nilai prestasi siswa berdasarkan KKM masih belum memenuhi standar Kriteria Ketuntasan Minimal yakni 70.00 .
Masalah utama yang perlu dijawab dalam penelitian ini adalah "Seberapa besar pengaruh sarana belajar terhadap prestasi belajar siswa di SDN Tarikolot II Kabupaten Majalengka?". Kemudian penelitian ini diharapkan dapat memberikan manfaat bagi semua pihak yang berkaitan dengan pendidikan, terutama bagi guru dan lembaga sekolah yang merupakan garda terdepan dalam meningkatkan kualitas belajar peserta didiknya, adapun manfaat penelitian ini yaitu:

1. Bagi Guru

Hasil penelitian ini diharapkan sebagai nilai tambah untuk meningkatkan ilmu pengetahuan dalam bidang pendidikan, guru harus kritis dan kreatif dalam memberikan masukan kepada kepala sekolah terkait dengan sarana belajar, guru harus kreatif dan terampil dalam memberikan pengajaran dan memperjelas pesan serta informasi sehingga dapat memperlancar dan meningkatkan prestasi belajar siswa. Kemudian guru harus dapat menggairahkan motivasi belajar siswa melalui pembelajaran kontekstual dan melibatkan sarana belajar secara optimal.

\section{Bagi Sekolah}

Hasil penelitian ini diharapkan sebagai informasi dalam penyelenggaraan pendidikan yang lebih baik, sekolah dapat memfasilitasi sarana belajar secara langsung dalam menunjang proses belajar mengajar seperti gedung, ruang kelas, meja, kursi, serta alat-alat media pengajaran.

\section{Sarana Belajar}

Sarana belajar adalah peralatan belajar yang di butuhkan dalam proses belajar agar pencapaian tujuan belajar dapat berjalan dengan lancar, teratur, efektif dan efisien (Roestiyah, 2004: 166). Kemudian menurut Mulyata (2002: 49) fasilitas atau sarana belajar adalah peralatan dan perlengkapan yang secara langsung di pergunakan dalam menunjang proses belajar mengajar seperti gedung, ruang kelas, meja, kursi, serta alat-alat media pembelajaran. Serta yang terakhir menurut Sanjaya (2009: 
55) mengungkapkan definisi dari sarana adalah segala sesuatu yang berkaitan secara langsung dengan peserta didik dan mendukung kelancaran serta keberhasilan proses belajar peserta didik yang meliputi media pembelajaran, alat-alat pelajaran, perlengkapan sekolah dan lain-lain.

Selain pengertian sarana belajar seperti yang dikemukakan di atas, sarana belajarpun mempunyai indikator yang menurut Dimyaiti dan Mudjiono (2009: 17) terdiri dari:

a. Sarana: 1) media pembelajaran, 2) alatalat pelajaran meliputi: buku pelajaran, buku bacaan, alat-alat praktikum, alatalat tulis, dan lain-lain. 3) perlengkapan sekolah meliputi: ruang kelas, lapangan olah raga, ruang ibadah, ruang kesenian, peralatan olah raga, perpustakaan, serta laboratorium.

b. Prasarana: 1) Jalan menuju sekolah. 2) Penerangan.

Lebih lengkapnya lagi dalam hubungannya belajar dengan proses belajar mengajar, ada dua jenis sarana pendidikan yaitu pertama, sarana pendidikan yang secara langsung digunakan dalam proses belajar mengajar, contohnya kapur tulis, atlas dan sarana pendidikan lainnya yang digunakan guru dalam mengajar. Kedua, sarana pendidikan yang secara tidak langsung berhubungan dengan proses belajar mengajar seperti lemari dan arsip sekolah yang merupakan sarana pendidikan secara tidak langsung digunakan oleh guru dalam proses belajar mengajar.

Bila ditinjau dari fungsi dan peranannya dalam proses belajar mengajar, maka sarana pendidikan dapat dibedakan menjadi:

a. Alat pelajaran, alat pelajaran adalah alat yang digunakan secara langsung dalam proses belajar mengajar. Alat ini mungkin berwujud buku tulis, gambargambar, alat-alat tulis menulis lain seperti kapur, penghapusan dan papan tulis maupun alat-alat praktek, semuanya termasuk ke dalam lingkup alat pelajaran. b. Alat peraga, alat peraga mempunyai arti yang luas. Alat peraga adalah semua alat pembantu pendidikan dan pengajaran, dapat berupa benda ataupun perbuatan dari yang tingkatannya paling konkrit sampai ke yang paling abstrak yang dapat mempermudah pemberian pengertian (penyampaian konsep) kepada siswa. Dengan bertitik tolak pada penggunaannya, maka alat peraga dapat dibedakan menjadi dua, yaitu:

1) Alat peraga langsung, yaitu jika guru menerangkan dengan menunjukkan benda sesungguhnya (benda dibawa ke kelas, atau siswa diajak ke benda tersebut).

2) Alat peraga tidak langsung, yaitu jika guru mengadakan penggantian terhadap benda sesungguhnya. Berturut-turut dari yang konkrit ke yang abstrak, maka alat peraga dapat berupa benda tiruan (miniatur), film, slide, foto, gambar, sketsa atau bagan. Disamping pembagian ini, ada lagi alat peraga atau peragaan yang berupa perbuatan atau kegiatan yang dilakukan oleh guru.

c. Media pengajaran, kata media berasal dari bahasa latin dan merupakan bentuk jamak dari kata medium yang secara harfiah berarti perantara atau pengantar. Media adalah alat bantu apa saja yang dapat dijadikan sebagai penyalur pesan guna mencapai tujuan pengajaran. Media merupakan sesuatu yang bersifat menyalurkan pesan dan dapat merangsang pikiran, perasaan dan kemauan siswa sehingga dapat mendorong terjadinya proses belajar pada siswa. Oleh karena itu, Penggunaan media secara kreatif akan memungkinkan siswa untuk belajar lebih baik dan dapat meningkatkan performa mereka sesuai dengan tujuan yang ingin dicapai.

Semua belajar memegang peranan yang sangat penting dalam mendukung tercapainya keberhasilan belajar dengan adanya pemanfaatan sarana belajar yang tepat dalam pembelajaran diharapkan mampu 
memberikan kemudahan dalam menyerap materi yang disampaikan. Pemanfaatan sarana belajar yang tepat merupakan faktor yang harus diperhatikan dalam kegiatan belajar, sebab aktivitas belajar akan berjalan dengan baik apabila ditunjang oleh sarana belajar yang baik dan memadai, dan sebaliknya jika tidak ada sarana dan prasarana yang baik menyebabkan siswa akan terhambat dalam belajar sehingga dapat mempengaruhi prestasi belajar siswa. Menurut Slameto (1995: 28) salah satu syarat keberhasilan belajar adalah bahwa belajar memerlukan sarana yang cukup, sarana atau fasilitas belajar yang menunjang kegiatan belajar siswa.

Pada Pasal 42 Peraturan Pemerintah nomor 19 tahun 2005 tentang Standar Nasional Pendidikan menyatakan bahwa (1). Setiap satuan pendidikan wajib memiliki sarana yang meliputi perabot, peralatan pendidikan, media pendidikan, buku dan sumber belajar yang lainnya, bahan habis pakai, serta perlengkapan lain yang diperlukan untuk menunjang proses pembelajaran yang teratur dan berkelanjutan. (2). Setiap satuan pendidikan wajib memiliki prasarana yang meliputi lahan ruang kelas, ruang pimpinan satuan pendidikan, ruang pendidik, ruang tata usaha, ruang perpustakaan, ruang laboratorium, ruang bengkel kerja, ruang unit produksi, ruang kantin, instalasi daya dan jasa, tempat berolahraga, tempat beribadah, tempat bermain, tempat berkreasi, dan ruang/tempat lain yang diperlukan untuk menunjang proses pembelajaran yang teratur dan berkelanjutan.

Menurut Arsyad (2006: 25) pemanfaatan sarana belajar memberikan beberapa manfaat yaitu:

a. Pemanfaatan sarana belajar dapat memperjelas pesan dan informasi sehingga dapat memperlancar dan meningkatkan proses dan hasil belajar.

b. Meningkatkan dan menggairahkan perhatian anak sehingga dapat menimbulkan motivasi belajar, interaksi yang lebih langsung antara siswa dan lingkungannya dan memungkinkan siswa untuk belajar sendiri sesuai dengan kemampuan minat.

c. Memberikan kesamaan pengalaman kepada siswa tentang peristiwa-peristiwa di lingkungan mereka, serta memungkinkan terjadinya interaksi langsung dengan guru, masyarakat dan lingkungannya, misal melalui karyawisata dan lain-lain.

Pemanfaatan sarana belajar yang baik akan memudahkan anak dalam melakukan aktivitas belajar sehingga anak lebih semangat dalam belajar. Sebaliknya, dengan kurangnya sarana belajar akan mengakibatkan anak kurang bersemangat dan kurang bergairah dalam belajar. Hal ini tentu saja akan mempengaruhi prestasi belajar anak.

\section{Prestasi Belajar}

a. Prestasi Belajar

Prestasi belajar adalah hasil yang dicapai oleh individu setelah mengalami suatu proses belajar dalam jangka waktu tertentu. Prestasi belajar juga diartikan sebagai kemampuan maksimal yang dicapai seseorang dalam suatu usaha yang menghasilkan pengetahuan atau nilai-nilai kecakapan (Sunartana, 2008: 17).

Prestasi belajar bisa juga disebut kecakapan aktual (actual ability) yang diperoleh seseorang setelah belajar, suatu kecakapan potensial (potensial ability) yaitu kemampuan dasar yang berupa disposisi yang dimiliki oleh individu untuk mencapai prestasi. Kecakapan aktual dan kecakapan potensial ini dapat dimasukkan kedalam suatu istilah yang lebih umum yaitu kemampuan (Yasa, $200: 14$ ).

Kemudian menurut Sevi (2008: 28) Prestasi belajar adalah hasil yang dicapai seorang siswa dalam usaha belajarnya sebagaimana dicantumkan di dalam nilai rapornya. Melalui prestasi belajar seorang siswa dapat mengetahui kemajuan-kemajuan yang telah dicapainya dalam belajar.

Pengertian di atas dapat disimpulkan bahwa prestasi belajar dapat diartikan sebagai hasil atau nilai kecakapan yang 
dicapai oleh siswa dari suatu usaha atau belajar dalam jangka waktu tertentu yang dapat memberikan kepuasan bagi siswa.

b. Faktor-faktor yang mempengaruhi
Prestasi Belajar
Mencapai prestasi belajar siswa Mencapai prestasi belajar siswa sebagaimana yang diharapkan, maka perlu diperhatikan beberapa faktor yang mempengaruhi prestasi belajar antara lain faktor yang terdapat dalam diri siswa (faktor intern), dan faktor yang terdiri dari luar siswa (faktor ekstern). Faktor-faktor yang berasal dari dalam diri anak bersifat fisiologis dan psikologis, sedangkan faktor yang berasal dari luar diri anak adalah faktor lingkungan, antara lain adalah keluarga dan masyarakat. Lebih jelasnya lagi dijabarkan di bawah ini menurut Djamarah (2008: 149) yaitu:

1) Faktor Intern

Faktor intern adalah faktor yang timbul dari dalam diri individu itu sendiri. Adapun yang dapat digolongkan ke dalam faktor intern yaitu kecerdasan atau intelegensi, bakat, minat, motivasi, dan kemampuan kognitif.

a) Kecerdasan atau intelegensi

Kecerdasan adalah kemampuan belajar disertai kecakapan untuk menyesuaikan diri dengan keadaan yang dihadapinya. Kemampuan ini sangat ditentukan oleh tinggi rendahnya intelegensi, adakalanya perkembangan ini ditandai oleh kemajuankemajuan yang berbeda antara satu anak dengan anak yang lainnya, sehingga seseorang anak pada usia tertentu sudah memiliki tingkat kecerdasan yang lebih tinggi dibandingkan dengan kawan sebayanya. Faktor intelegensi merupakan suatu hal yang tidak diabaikan dalam kegiatan belajar mengajar. Kecerdasan merupakan salah satu aspek yang penting dan sangat menentukan berhasil tidaknya studi seseorang. Kalau seorang murid mempunyai tingkat kecerdasan normal atau di atas normal maka secara potensi orang tersebut dapat mencapai prestasi yang tinggi. Jadi intelegensi adalah semakin tinggi kemampuan intelegensi seseorang siswa maka semakin besar peluangnya untuk meraih sukses. Sebaliknya semakin rendah kemampuan intelegensi seseorang siswa maka semakin kecil peluangnya untuk meraih sukses.

b) Bakat

Bakat adalah kemampuan tertentu yang telah dimiliki seseorang sebagai kecakapan pembawaan. Bakat dalam hal ini lebih dekat pengertiannya dengan kata aptitude yang berarti kecakapan, yaitu mengenai kesanggupan-kesanggupan tertentu. Bakat adalah potensi atau kemampuan kalau diberikan kesempatan untuk dikembangkan melalui belajar akan menjadi kecakapan yang nyata. Bakat diartikan sebagai kemampuan individu untuk melakukan tugas tanpa banyak bergantung pada upaya pendidikan dan latihan. Menurut Sunarto dan Hartono (dalam Djamarah, 2008: 176), bakat memungkinkan seseorang untuk mencapai prestasi dalam bidang tertentu, akan tetapi diperlukan latihan, pengetahuan, pengalaman, dan dorongan atau motivasi agar bakat itu dapat terwujud. Pendapat di atas dijelaskan bahwa tumbuhnya keahlian tertentu, pada seseorang sangat ditentukan oleh bakat yang dimilikinya sehubungan dengan bakat ini dapat mempunyai tinggi rendahnya prestasi belajar pada bidangbidang studi tertentu. Dalam proses belajar terutama belajar keterampilan, bakat memegang peranan penting dalam mencapai suatu hasil akan prestasi yang baik. Apalagi seorang guru atau orang tua memaksa anaknya untuk melakukan sesuatu yang tidak sesuai dengan bakatnya, maka akan merusak keinginan anak tersebut.

c) Minat

Menurut Slameto (dalam Djamarah, 2008: 202) minat adalah suatu rasa lebih dan rasa keterkaitan pada suatu hal atau aktivitas, tanpa ada yang menyuruh. Minat pada dasarnya adalah penerimaan akan suatu hubungan antara diri sendiri dengan suatu di luar diri. Semakin kuat atau dekat hubungan tersebut, semakin besar minat. Minat adalah kecenderungan yang tetap 
untuk memperhatikan dan mengenang beberapa kegiatan, kegiatan yang diminati seseorang, diperhatikan terus yang disertai dengan rasa sayang. Minat merupakan suatu kondisi yang terjadi apabila seseorang melihat ciri-ciri atau arti sementara situasi yang dihubungkan dengan keinginan-keinginan atau kebutuhan-kebutuhannya sendiri. Berdasarkan pendapat di atas, jelaslah bahwa minat besar pengaruhnya terhadap belajar atau kegiatan. Bahkan pelajaran yang menarik minat siswa lebih mudah dipelajari dan disimpan karena minat menambah kegiatan belajar. Minat belajar yang telah dimiliki siswa merupakan salah satu faktor yang dapat mempengaruhi hasil belajarnya. Apabila seseorang mempunyai minat yang tinggi terhadap sesuatu hal maka akan terus berusaha untuk melakukan sehingga apa yang diinginkannya dapat tercapai sesuai dengan keinginannya.

d) Motivasi

Menurut Nasution (dalam Djamarah, 2008: 149) Motivasi adalah segala daya yang mendorong seseorang untuk melakukan sesuatu. Motivasi merupakan pergerakan siswa untuk melakukan sesuatu atau ingin melakukan sesuatu. Selanjutnya motivasi dalam belajar adalah faktor yang penting karena hal tersebut merupakan keadaan yang mendorong siswa untuk melakukan belajar. Persoalan mengenai motivasi dalam belajar adalah bagaimana cara mengatur agar motivasi dapat ditingkatkan. Demikian pula dalam kegiatan belajar mengajar seorang anak didik akan berhasil jika mempunyai motivasi untuk belajar. Perkembangannya motivasi dapat dibedakan menjadi dua macam yaitu: motivasi instrinsik dan motivasi ekstrinsik. Motivasi instrinsik dimaksudkan dengan motivasi yang bersumber dari dalam diri seseorang yang atas dasarnya kesadaran sendiri untuk melakukan sesuatu pekerjaan belajar. Sedangkan motivasi ekstrinsik dimaksudkan dengan motivasi yang datangnya dari luar diri seseorang siswa yang menyebabkan siswa tersebut melakukan kegiatan belajar. Seorang guru harus berusaha memberikan motivasi dengan segala kemampuan yang ada untuk mengarahkan perhatian siswa kepada sasaran tertentu. Dengan adanya dorongan ini dalam diri siswa akan timbul inisiatif dengan alasan mengapa ia menekuni pelajaran.

\section{2) Faktor Ekstern}

Faktor ekstern adalah faktor-faktor yang dapat mempengaruhi prestasi belajar yang sifatnya di luar diri siswa, yaitu beberapa pengalaman-pengalaman, keadaan keluarga dan lingkungan sekitarnya. Pengaruh lingkungan ini pada umumnya bersifat positif dan tidak memberikan paksaan kepada individu, faktor ekstern yang dapat mempengaruhi belajar adalah keadaan keluarga, keadaan sekolah dan lingkungan masyarakat.

\section{a) Keadaan Keluarga}

Keluarga merupakan lingkungan terkecil dalam masyarakat tempat seseorang dilahirkan dan dibesarkan. Sebagaimana yang dijelaskan oleh Slameto (2003: 2) bahwa keluarga adalah lembaga pendidikan pertama dan utama. Adanya rasa aman dalam keluarga sangat penting dalam keberhasilan seseorang dalam belajar. Rasa aman itu membuat seseorang akan terdorong untuk belajar, karena rasa aman merupakan salah satu kekuatan pendorong dari luar yang menambah motivasi untuk belajar. Keluarga merupakan lingkungan pendidikan yang pertama, karena dalam keluarga inilah anak pertama-tama mendapatkan pendidikan dan bimbingan, sedangkan tugas utama dalam keluarga bagi pendidikan anak ialah sebagai peletak dasar bagi pendidikan akhlak dan pandangan hidup keagamaan. Orang tua hendaknya menyadari bahwa pendidikan dimulai dari keluarga. Sedangkan sekolah merupakan pendidikan lanjutan. Peralihan pendidikan informal ke lembaga-lembaga formal memerlukan 
kerjasama yang baik antara orang tua dan guru sebagai pendidik dalam usaha meningkatkan hasil belajar anak. Jalan kerjasama yang perlu ditingkatkan, dimana orang tua harus menaruh perhatian yang serius tentang cara belajar anak di rumah. Perhatian orangtua dapat memberikan dorongan dan motivasi sehingga anak dapat belajar dengan tekun, karena anak memerlukan waktu, tempat dan keadaan yang baik untuk belajar.

b) Keadaan Sekolah

Sekolah merupakan lembaga pendidikan formal pertama yang sangat penting dalam menentukan keberhasilan belajar siswa, karena itu lingkungan sekolah yang baik dapat mendorong untuk belajar yang lebih giat. Keadaan sekolah ini meliputi cara penyajian pelajaran, hubungan guru dengan siswa, alat-alat pelajaran dan kurikulum. Hubungan antara guru dan siswa kurang baik akan mempengaruhi hasil-hasil belajarnya. Guru dituntut untuk menguasai bahan pelajaran yang akan diajarkan, dan memiliki tingkah laku yang tepat dalam mengajar. Guru harus dituntut untuk menguasai bahan pelajaran yang disajikan, dan memiliki metode yang tepat dalam mengajar. Guru harus mampu mengelola seluruh proses kegiatan belajar-mengajar dengan menciptakan kondisi-kondisi belajar sedemikian rupa sehingga setiap anak dapat belajar secara efektif dan efisien.

c) Lingkungan Masyarakat Lingkungan juga merupakan salah satu faktor yang tidak sedikit pengaruhnya terhadap hasil belajar siswa dalam proses pelaksanaan pendidikan, karena lingkungan alam sekitar sangat besar pengaruhnya terhadap perkembangan pribadi anak, sebab dalam kehidupan sehari-hari anak akan lebih banyak bergaul dengan lingkungan dimana anak itu berada. Lingkungan masyarakat dapat menimbulkan kesukaran belajar anak, terutama anak-anak yang sebayanya.
Apabila anak-anak yang sebaya merupakan anak-anak yang rajin belajar, maka anak akan terangsang untuk mengikuti jejak mereka. Sebaliknya bila anak-anak di sekitarnya merupakan kumpulan anak-anak nakal yang berkeliaran tidak menutup kemungkinan anakpun dapat terpengaruh pula. Lingkungan akan membentuk kepribadian anak, karena dalam pergaulan sehari-hari seorang anak akan selalu menyesuaikan dirinya dengan kebiasaan-kebiasaan lingkungannya, apabila seorang siswa bertempat tinggal di suatu lingkungan temannya yang rajin belajar maka kemungkinan besar hal tersebut akan membawa pengaruh pada dirinya, sehingga is akan turut belajar sebagaimana temannya.

\section{c. Pengukuran prestasi belajar atau scoring}

Skor adalah harga kuantitatif suatu jawaban terhadap item dalam tes. Pemberian skor dapat memperoleh deskripsi mengenai performansi siswa dalam tes, dapat melakukan analisis kuantitatif terhadap tes dan kaitannya dengan variabel lain, dan yang paling penting dapat memberikan evaluasi terhadap performansi subjek dalam bentuk nilai (Anwar, 2005: 8)

Menurut Djiwandono (2008: 57) scoring adalah proses pengubahan jawaban tes menjadi angka dan angka penskoran tersebut diubah menjadi nilai, di Indonesia nilai berbentuk angka-angka dengan melalui proses tertentu. Penggunaan simbol untuk menyatakan nilai secara resmi antara $0-10$, dan ada juga yang menggunakan $0-100$, atau $0-4$, dan ada yang menggunakan huruf A. B, C, D, E.

Pengukuran prestasi belajar mempunyai kriteria acuan penilaian yang pada awalnya dilakukan tes yang pada umumnya dapat dibeda-bedakan berdasarkan cara melakukan interprestasi terhadap hasil pekerjaan peserta dalam penetapan nilai akhir. Langkah pertama adalah melakukan pemeriksaan yaitu memberi tanda pada jawaban yang salah untuk mengetahui jumlah 
jawaban yang benar. Langkah kedua adalah pembijian yaitu menghitung nilai jumlah jawaban benar, dan menuliskan jumlahnya.

Langkah pengukuran prestasi belajar di atas yang disebut dengan penskoran, dan selanjutnya skor-skor tersebut dijadikan satu dengan skor-skor lain serta telah disesuaikan pengaturannya dengan standar tertentu. Contoh, pada tes dari suatu modul selalu disertakan juga kunci dan pedoman scoring, scoring maksimum pada setiap soal tidak sama tergantung pada jumlah soal dan bobot soal tes tersebut.

Prestasi belajar siswa dapat diketahui dengan cara mengubah skor mentah menjadi skor berstandar 100. Guru berpedoman pada aturan yang sudah ditetapkan sekolah untuk penskoran dalam prestasi belajar sebagai berikut: Istimewa: 01- 100, Amat baik: 8190, Baik 70-80, Cukup: 61-70, Kurang: 5160, Sangat kurang: $<50$

Penentuan nilai akhir siswa dalam rapor dirumuskan dengan cara:

$\mathrm{NA}=\frac{2 T+3 H+5 U}{10}$

Keterangan : $\mathrm{T}=$ Nilai tugas; $\mathrm{H}=$ Nilai ulangan harian; $\mathrm{U}=$ Nilai ulangan umum

Contoh pengukuran prestasi belajar pada siswa, misal: nilai tugas 60, nilai ulangan harian 70, nilai ulangan umum 80. Jadi: NA $=2(60)+3(70)+5(80) / 10=73$, Jadi siswa tersebut mempunyai prestasi belajar yang baik.

\section{Metode Penelitian}

Metode yang akan digunakan dalam penelitian ini adalah Explanatory Survey Method. Menurut Sanapiah Faisal (2007: 18) menjelaskan penelitian eksplanasi yaitu suatu penelitian yang dimaksudkan untuk menemukan dan mengembangkan teori, sehingga hasil atau produk penelitiannya dapat menjelaskan kenapa atau mengapa terjadinya sesuatu gejala atau kenyataan sosial tertentu.

Dengan penggunaan metode survey eksplanasi ini, peneliti melakukan pengamatan untuk memperoleh gambaran yaitu variabel variabel Sarana Belajar, dan variabel Prestasi Belajar. Objek yang diuji dalam penelitian ini adalah siswa di Kelas V SDN Tarikolot II Kabupaten Majalengka.

Populasi penelitian ini adalah seluruh siswa kelas V SDN Tarikolot II Kabupaten Majalengka sebanyak 17 orang. Kemudian sampel dalam penelitian ini diambil seluruh siswa yang berjumlah 17 orang dengan menggunakan teknik total sampling.

\section{Kisi-kisi Instrumen}

Pertanyaan tentang sarana belajar dituangkan ke dalam kuesioner, meliputi: media pembelajaran; alat-alat pelajaran meliputi buku pelajaran, buku bacaan, alatalat praktikum, alat-alat tulis; perlengkapan sekolah meliputi ruang kelas, lapangan olah raga, ruang ibadah, ruang kesenian, peralatan olah raga, perpustakaan, laboratorium.

Untuk perumusan alternatif jawaban, setiap jawaban item instrumen menggunakan gradasi dari sangat positif sampai sangat negatif. Jawaban yang digunakan dalam penelitian ini adalah

SS = Sangat Setuju

$\mathrm{S} \quad=$ Setuju

$\mathrm{R} \quad=$ Ragu-ragu

TS = Tidak setuju

STS = Sangat tidak setuju

Yang terakhir adalah penetapan Skala penilaian angket yaitu dengan memberikan nilai pembobotan untuk setiap jenis pertanyaan yang berskala ordinal. Skor 5-43-2-1 digunakan untuk pernyataan yang bersifat mendukung dan Skor 1-2-3-4-5 untuk pernyataan yang sifatnya tidak mendukung. Seperti tabel skala Likert di bawah ini:

\begin{tabular}{|c|l|c|c|}
\hline No & \multicolumn{1}{|c|}{ Jawaban } & Positif & Negatif \\
\hline 1 & Sangat Setuju & 5 & 1 \\
\hline 2 & Setuju & 4 & 2 \\
\hline 3 & Kurang Setuju & 3 & 3 \\
\hline 4 & Tidak Setuju & 2 & 4 \\
\hline 5 & Sangat Tidak Setuju & 1 & 5 \\
\hline
\end{tabular}

Sumber: Sugiyono (2009: 134)

Untuk instrumen prestasi belajar yaitu dari nilai siswa yang didapatkan dari nilai ulangan harian, tugas dan nilai rapor. 
Sebelum angket digunakan untuk mengumpulkan data dari subjek penelitian, maka angket harus memenuhi 2 persyaratan penting yaitu valid dan reliabel.

a. Uji Validitas

Uji validitas dengan menggunakan Rumus korelasi product moment dengan rumus :

$$
r=\frac{n(\Sigma x y)-(\Sigma x \Sigma y)}{\left.\sqrt{n \sum x y^{2}-}(\mathrm{n} \Sigma x y)^{2}\right\}\left\{n \Sigma x y^{2}-(\mathrm{n} \Sigma x y)^{2}\right\}}
$$

\section{Keterangan:}

$\mathrm{X}=$ Skor item pertanyaan,

$\mathrm{Y}=$ Skor total pernyataan,

$\mathrm{XY}=$ skor pertanyaan dikalikan dengan skor total.

$\mathrm{n} \quad=$ Jumlah responden

Kriteria yang digunakan apabila rhit > rtabel, maka dinyatakan valid (mengukur apa yang diukur).

b. Uji Reliabilitas

Uji reliabilitas dengan menggunakan rumus koefisien Alpha Cronbach dan dinyatakan reliable bila nilai $r_{\text {alpha }}>r_{a l p a}$ Cronbach Rumus Alpha Cronbach:

$$
a=\frac{k}{k-1}\left\{1-\frac{\Sigma s_{1}^{2}}{s_{1}^{2}}\right.
$$

$\mathrm{a}=$ reliabilitas instrument

$\mathrm{k} \quad$ = banyaknya butir pertanyaan

$\Sigma s_{1}^{2}=$ jumlah varian butiran

$\mathrm{S} 1=$ varian total

dengan telah dipenuhinya kedua uji tersebut di atas (uji validitas dan uji reabilitas) terhadap beberapa responden di luar sampel, dan mendapatkan hasil yang positif yaitu nilai $r_{\text {hitung }}$ lebih besar dari $r_{\text {tabel }}$, maka instrumen penelitian sudah siap untuk diberikan pada sampel.

\section{Pengolahan Data}

Proses pengolahan ini dilakukan dengan tahapan sebagai berikut:

a. Penyuntingan (editing), setiap lembar instrumen yang telah diisi adalah dokumen tentang responden. dibetulkan kembali dengan menghubungi responden yang bersangkutan.

b. Pemberian Kode (Coding), tahap selanjutnya setelah editing adalah pemberian kode (sandi) pada variabel dan data yang telah terkumpul melalui lembar instrumen.

c. Pemeriksaan Data (Sorting), data hasil penelitian oleh peneliti akan diperiksa apakah data tersebut lengkap atau ada yang tidak lengkap.

d. Pemasukan Data (Entry), sebelum dilakukan pemasukan data, maka dibuat templete entry data dengan menggunakan perangkat lunak MS Excel.

e. Pembersihan Data (Deaning), pembersihan data (deaning) meliputi:

1) Kelengkapan data,

2) Kelengkapan variabel yang diamati,

3) Jumlah siswa sesuai dengan daftar hadir,

4) Distribusi frekuensi masing-masing variabel sesuai dengan jumlah responden.

f. Pengeluaran Informasi, hasil pengolahan data dibuat dalam bentuk tabel distribusi frekuensi, nilai koefisien korelasi product moment.

\section{Teknik Analisis Data}

Analisis ini dilakukan untuk memperoleh gambaran baik variabel bebas maupun variabel terikat, disajikan secara deskriptif dalam means, median, nilai minimum dan maksimum, serta standar deviasi. Hal ini akan dianalisis dengan menggunakan perhitungan uji statistik melalui langkah-langkah sebagai berikut:

a. Uji Prasyarat Analisis

1) Uji Normalitas Data, uji prasyarat analisis data dengan menggunakan uji normalitas data yang dimaksudkan untuk memperlihatkan bahwa data sampel berasal dari populasi yang berdistribusi normal. Untuk lebih memperkuat pengujian normalitas dilakukan penguji ini dengan menggunakan one sample kolmomogorov-smirnov dengan menggunakan SPSS versi 20. Kriteria normalitas pada one sample kolmomogorov-smirnov adalah jika asymp $\operatorname{sig}\left(2_{\text {tailed }}\right)>$ a $(0,05)$ maka 
sampel tidak berdistribusi normal. asymp $\operatorname{sig}\left(2_{\text {tailed }}\right)<$ a $(0,05)$ maka sampel berdistribusi normal.

2) Uji Homogenitas, uji homogenitas dimaksudkan untuk memperlihatkan bahwa dua atau lebih kelompok data sampel berasal dari populasi yang memiliki variansi yang sama. Pada analisis regresi, persyaratan analisis yang dibutuhkan adalah bahwa galat regresi untuk setiap pengelompokan berdasarkan variabel terikatnya memiliki variansi yang sama. Uji homogenitas menggunakan Test Homogenity of Variance. Interpretasi dilakukan dengan memilih salah satu statistik, yaitu statistik yang didasarkan pada rata-rata (Based on Mean). Dengan demikian, kehomogenan dipenuhi jika hasil uji tidak signifikan untuk suatu taraf signifikasi (a) tertentu (Biasanya $\mathrm{a}=0.05$ atau 0.01). Sebaliknya, jika hasil uji signifikan maka kenormalan tidak dipenuhi.

b. Uji Hipotesis, yaitu uji korelasi Product Moment. Analisis data pada penelitian ini dimaksudkan untuk menguji hipotesis yang diajukan, apakah diterima atau ditolak. Berdasarkan pertimbangan hipotesis yang diuji, tujuan penelitian, jenis data dan variabel penelitian, peneliti melakukan pendekatan statistik untuk mengolah data. Uji hipotesis yang digunakan adalah dengan Analisis korelasi Product Moment karena skala datanya rasio. Analisis korelasi digunakan untuk mengetahui derajat hubungan antara variabel $\mathrm{X}$ dengan variabel $\mathrm{Y}$. Ukuran yang dipakai untuk mengetahui derajat hubungan terutama untuk data kuantitatif digunakan koefisien korelasi. Hipotesis statistik yang akan diuji adalah terdapat kontribusi yang positif dan signifikan dari sarana belajar terhadap prestasi belajar siswa di Kelas V SD Negeri Tarikolot II Kab. Majalengka. Sebagai perhitungannya digunakan sebagai berikut:

$$
r=\frac{n(\Sigma X Y)-(\Sigma X)(\Sigma Y)}{\sqrt{\left[n \cdot \Sigma \mathrm{X}^{2}-(\Sigma \mathrm{X})^{2}\right]} \sqrt{\left[n \cdot \Sigma \mathrm{Y}^{2}-(\Sigma \mathrm{Y})^{2}\right]}}
$$

Keterangan:

$\mathrm{r} \quad=$ Koefisien korelasi

$\Sigma \mathrm{X}=$ Jumlah skor item

$\Sigma \mathrm{X}=$ Jumlah skor total (item)

$\mathrm{n}=$ Jumlah responden

Keberartian korelasi dimaksudkan untuk mengetahui berati atau tidaknya hubungan antara variabel $\mathrm{X}$ dan $\mathrm{Y}$, dengan menggunakan kriteria penafsiran koefisien korelasi. Sedangkan arti harga $r$ akan dikonsultasikan dengan tabel interpretasi nilai $r$ sebagai berikut:

\begin{tabular}{|c|l|}
\hline Interval & Tingkat Hubungan \\
\hline $0,800-1,000$ & Sangat Kuat \\
\hline $0,600-0,799$ & Kuat \\
\hline $0,400-0,599$ & Cukup Kuat \\
\hline $0,200-0,399$ & Rendah \\
\hline $0,000-0,199$ & Sangat Rendah \\
\hline \multicolumn{2}{|c|}{ Sumber : Sugiyono, 2009. }
\end{tabular}

Setelah koefisien korelasi didapatkan, maka perlu untuk meyakinkan kontribusi dari variabel $\mathrm{X}$ terhadap $\mathrm{Y}$ dengan menguji hipotesisnya.

Pengujian hipotesis bertujuan untuk menguji apakah hipotesis yang telah dilakukan pada penelitian ini diterima atau tidak. Uji signifikansi untuk mencari makna hubungan variabel $\mathrm{x}$ terhadap y, uji coba signifikansi dengan rumus:

dimana:

$$
\text { thitung }=\frac{r \cdot r \sqrt{-2}}{\sqrt{1-r 2}}
$$

$\mathrm{t}_{\text {hitung }}=$ nilai hitung,

$\mathrm{r} \quad=$ koefisien korelasi

$\mathrm{n} \quad=$ jumlah responden

interpretasi :

1) Nilai $t_{\text {hitung }}>t_{\text {tabel }}$, maka Ha diterima, yang berarti ada hubungan yang bermakna antara sarana belajar dengan prestasi belajar.

2) Nilai $t_{\text {hitung }} \leq t_{\text {tabel }}$, maka Ha ditolak, yang berarti tidak ada hubungan yang bermakna antara sarana belajar dengan prestasi belajar. 
Selanjutnya untuk menyatakan besar kecilnya sumbangan variabel $\mathrm{x}$ terhadap y dapat ditentukan dengan rumus koefisien determinan yaitu $\mathrm{KD}=\mathrm{r}^{2} \mathrm{x} 100 \%$.

\section{Hasil dan Pembahasan}

\section{Persiapan Pengumpulan Data}

Tahap persiapan merupakan rangkaian kegiatan sebelum memulai pengumpulan dan pengolahan data. Dalam tahap awal ini disusun hal-hal penting yang harus segera dilakukan dengan tujuan untuk mengefektifkan waktu dan pekerjaan. Dalam rangka memperoleh data pengaruh sarana belajar terhadap prestasi belajar siswa khususnya pada mata pelajaran IPS, peneliti membuat instrumen berupa kuesioner/angket yang terdiri dari 7 pertanyaan yang harus diisi oleh siswa. Dalam rangka menguji kebaikan alat pengumpulan data penelitian tentang validitas dan reliabilitasnya, maka sebelum kuesioner/angket ini disebarkan kepada responden terlebih dahulu penulis mengadakan uji coba terhadap siswa dari kelas lain yang tidak terpilih menjadi sampel sebanyak 20 orang, dengan tujuan memperoleh hasil yang baik serta kualitas angket yang telah dibuat. Adapun hasil pengujian dapat penulis sajikan berikut ini:

1. Uji Validitas Instrumen

Berdasarkan hasil uji validitas, didapat nilai validitas $r_{\text {hitung }}$ semuanya lebih besar dari $\mathrm{r}_{\text {tabel }} / \mathrm{r}_{\text {hitung }}>\mathrm{r}_{\text {tabel }}$. Dengan $\alpha=5 \%$ dan $\mathrm{N}=20$ harga (r) pada table adalah 0,444. Angket yang disebarkan kepada siswa SDN Tarikolot II dianggap telah memiliki konstruksi validitas yang memadai. Dari ke 7 pernyataan angket tersebut setelah diuji validitas, hasilnya semuanya valid.

2. Uji Reliabilitas Instrumen

Berdasarkan perhitungan uji reliabilitas, dengan $r_{\text {table }}=0,444$ dari 7 item pernyataan angket, semua item soal dinyatakan valid dan $r_{\text {hitung }}>r_{\text {tabel }} / \mathrm{r}_{\text {hitung }}$ lebih besar dari $\mathrm{r}_{\text {table }}=1,16>0,444$.

Setelah diuji cobakan kepada 20 orang siswa, ternyata hasilnya memuaskan, selanjutnya penelitian dilakukan pada sampel yaitu seluruh siswa kelas V SDN Tarikolot II sebanyak 17 orang.

\section{Hasil Analisis Data Penelitian}

Tujuan dari pada penelitian adalah untuk mendapatkan data berupa angka yang kemudian diolah menggunakan perhitungan statistik, yang dapat menghasilkan kesimpulan berupa hasil penelitian. Hasil pengambilan data yang dilakukan pada sampel penelitian dapat terlihat dalam tabel di bawah ini:

Data Hasil Angket Penelitian

\begin{tabular}{|c|c|c|c|c|c|c|c|c|}
\hline No & \multicolumn{7}{|c|}{ Skor tiap Item Angket } & Jumlah \\
\hline 1 & 5 & 5 & 5 & 4 & 4 & 5 & 4 & 32 \\
\hline 2 & 5 & 3 & 3 & 3 & 3 & 3 & 3 & 23 \\
\hline 3 & 5 & 5 & 4 & 4 & 4 & 4 & 4 & 30 \\
\hline 4 & 5 & 4 & 4 & 3 & 4 & 3 & 4 & 27 \\
\hline 5 & 4 & 4 & 5 & 3 & 4 & 4 & 4 & 28 \\
\hline 6 & 5 & 5 & 5 & 4 & 4 & 5 & 4 & 32 \\
\hline 7 & 4 & 4 & 4 & 4 & 4 & 4 & 4 & 28 \\
\hline 8 & 5 & 4 & 4 & 4 & 4 & 5 & 4 & 30 \\
\hline 9 & 3 & 3 & 3 & 3 & 4 & 3 & 4 & 23 \\
\hline 10 & 5 & 5 & 4 & 4 & 4 & 4 & 4 & 30 \\
\hline 11 & 5 & 5 & 4 & 4 & 4 & 4 & 4 & 30 \\
\hline 12 & 5 & 4 & 4 & 4 & 4 & 4 & 4 & 29 \\
\hline 13 & 5 & 5 & 4 & 3 & 4 & 4 & 4 & 29 \\
\hline 14 & 5 & 5 & 4 & 4 & 5 & 5 & 4 & 32 \\
\hline 15 & 4 & 4 & 4 & 4 & 3 & 3 & 3 & 25 \\
\hline 16 & 5 & 5 & 5 & 5 & 5 & 5 & 5 & 35 \\
\hline 17 & 5 & 4 & 4 & 5 & 5 & 4 & 5 & 32 \\
\hline
\end{tabular}

Data hasil penelitian

\begin{tabular}{|c|c|c|}
\hline \multirow{2}{*}{$\begin{array}{c}\text { Nama } \\
\text { Resp }\end{array}$} & \multicolumn{2}{|c|}{ Hasil Penelitian } \\
\cline { 2 - 3 } & Sarana Belajar & Prestasi Belajar \\
\hline 1 & 32 & 80 \\
\hline 2 & 23 & 75 \\
\hline 3 & 30 & 82 \\
\hline 4 & 27 & 78 \\
\hline 5 & 28 & 80 \\
\hline 6 & 32 & 85 \\
\hline 7 & 28 & 76 \\
\hline 8 & 30 & 80 \\
\hline 9 & 23 & 75 \\
\hline 10 & 30 & 80 \\
\hline 11 & 30 & 78 \\
\hline 12 & 29 & 70 \\
\hline 13 & 29 & 70 \\
\hline 14 & 32 & 85 \\
\hline
\end{tabular}




\begin{tabular}{|c|c|c|}
\hline \multirow{2}{*}{$\begin{array}{c}\text { Nama } \\
\text { Resp }\end{array}$} & \multicolumn{2}{|c|}{ Hasil Penelitian } \\
\cline { 2 - 3 } & Sarana Belajar & Prestasi Belajar \\
\hline 15 & 25 & 70 \\
\hline 16 & 35 & 76 \\
\hline 17 & 32 & 85 \\
\hline Jmlh & $\mathbf{4 9 5}$ & $\mathbf{1 3 2 5}$ \\
\hline
\end{tabular}

Data yang digunakan untuk menganalisis hasil penelitian ini adalah data yang diperoleh dari penyebaran angket dan prestasi belajar siswa khususnya pada mata pelajaran IPS. Data selanjutnya dianalisis melalui uji statistik untuk mengetahui pengaruh dari sarana belajar terhadap prestasi belajar siswa pada mata pelajaran IPS. Berikut ini akan di uraikan deskripsi data dari masing-masing hasil tes:

a. Nilai rata-rata, standar deviasi, varians, nilai tertinggi, nilai terendah

Deskripsi data hasil penyebaran angket dan prestasi belajar siswa pada mata pelajaran IPS dari sampel penelitian dapat dilihat pada tabel di bawah ini:

Tabel Nilai Rata-Rata, Standar Deviasi, Varians, Nilai Tertinggi, Nilai Terendah

\begin{tabular}{|l|c|c|c|c|c|c|}
\hline Variabel & N & $\begin{array}{c}\text { Nilai } \\
\text { terendah }\end{array}$ & $\begin{array}{c}\text { Nilai } \\
\text { tertinggi }\end{array}$ & $\begin{array}{c}\text { Rata- } \\
\text { rata }\end{array}$ & $\begin{array}{c}\text { Standar } \\
\text { deviasi }\end{array}$ & varians \\
\hline $\begin{array}{l}\text { Sarana } \\
\text { belajar }\end{array}$ & 17 & 23 & 35 & 29,12 & 3,25 & 10,16 \\
\hline $\begin{array}{l}\text { Prestasi } \\
\text { Belajar }\end{array}$ & 17 & 70 & 85 & 77,94 & 4,98 & 24,80 \\
\hline
\end{tabular}

Berdasarkan tabel di atas, dapat diuraikan bahwa data yang dihasilkan dari penyebaran angket mengenai sarana belajar yang didapat dari jumlah sampel sebanyak 17 orang adalah sebagai berikut rata-rata 29,12 dengan nilai terendah 23 dan nilai tertinggi 35 , standar deviasi 3,25 serta varians sebesar 10,16 . Sedangkan, data yang didapat dari prestasi belajar siswa pada mata pelajaran IPS yang didapat dari jumlah sampel sebanyak 17 orang adalah rata-rata 77,94 dengan nilai terendah 70 dan nilai tertinggi 85 , standar deviasi 4,98 serta varians sebesar 24.80 .

\section{b. Uji Normalitas}

Uji normalitas dilakukan untuk mengetahui apakah penyebaran data variabel yang diteliti berdistribusi normal atau tidak normal, yang selanjutnya kita dapat menentukan apakah pengujian yang digunakan menggunakan uji statistik parametrik atau non-parametrik. Bila data berdistribusi normal maka digunakan uji statistik parametrik, sedangkan bila distribusi data tidak normal maka digunakan uji statistik non-parametrik. Uji normalitas dalam penelitian ini menggunakan uji Kolmogorov-Smirnov.

Hasil penghitungan uji normalitas data penelitian ini diperoleh melalui penghitungan dengan menggunakan SPSS 20 dengan alat uji Kolmogorov-Smirnov. Adapun dasar pengambilan keputusan adalah jika nilai sig. atau nilai probability $>0.05$ maka dikatakan distribusi data normal, dan jika nilai sig. atau nilai probability $<0.05$ maka dikatakan distribusi data tersebut tidak normal. Berikut adalah hasil uji normalitas dari data-data penelitian yang telah diperoleh dari masingmasing tes. Data hasil uji normalitas tersebut dapat dilihat pada tabel di bawah ini:

\begin{tabular}{|c|c|c|c|c|}
\hline \multicolumn{5}{|c}{ Hasil Uji Normalitas } \\
\hline No & $\begin{array}{c}\text { Variabel } \\
\text { penelitian }\end{array}$ & df & $\begin{array}{c}\text { Kasil Uji } \\
\text { Kolmogorov } \\
\text { - smirnov }\end{array}$ & Keputusan \\
\hline 1 & Sarana belajar & 17 & 0.200 & Normal \\
\hline 2 & Prestasi belajar & 17 & 0.200 & Normal \\
\hline
\end{tabular}

\section{c. Uji Homogenitas}

Uji Homogenitas dilakukan dengan maksud untuk mengetahui tingkat homogen varians dari masing-masing data tes. Uji ini diperlukan sebagai syarat dalam membandingkan data. Uji ini dihitung menggunakan lavene test $(\alpha=0,05)$. Dengan ketentuan bila nilai sig. atau nilai probabilitas lebih besar dari 0,05 ( $\mathrm{Sig}$ > 0,05), maka data tersebut homogen, sedangkan jika nilai Sig. atau nilai Probilitas lebih kecil dari 0,05 (Sig. < 0,05), maka data tersebut tidak homogen. Hasil penghitungan 
dari uji homogenitas ini bisa dilihat dari tabel di bawah ini:

Hasil Uji Homogenitas

\begin{tabular}{|c|c|c|}
\hline Data Penelitian & Nilai Sig & Keputusan \\
\hline $\begin{array}{c}\text { Sarana belajar terhadap } \\
\text { prestasi belajar }\end{array}$ & 0.137 & Homogen \\
\hline
\end{tabular}

Dengan melihat tabel di atas, dapat disimpulkan bahwa data-data penelitian yang diperoleh adalah Homogen. Karena data penelitian diatas normal dan homogen, maka uji statistik yang digunakan adalah uji statistik parametrik dengan menggunakan uji korelasi Product moment.

\section{d. Analisis Korelasional}

Selanjutnya untuk mengetahui pengaruh sarana belajar (variabel $\mathrm{X}$ ) terhadap prestasi belajar siswa pada mata pelajaran IPS (variabel Y), penulis menggunakan analisis korelasi dengan menggunakan rumus korelasi product moment yang hasilnya dapat dilihat pada tabel berikut ini.

Uji Korelasi

\begin{tabular}{|c|c|c|c|c|}
\hline Penelitian & $\mathrm{dk}$ & Korelasi/R & Sig. & Ksmpln \\
\hline $\begin{array}{c}\text { Sarana belajar } \\
\text { terhadap } \\
\text { prestasi belajar }\end{array}$ & 17 & 0,513 & 0,018 & $\begin{array}{c}\text { Korelasi } \\
\text { Sedang }\end{array}$ \\
\hline
\end{tabular}

Berdasarkan hasil penghitungan dengan rumus korelasi product moment, terlihat bahwa nilai korelasi yang dihasilkan antara variabel $\mathrm{x}$ yang dalam hal ini pengaruh sarana belajar terhadap variabel y yakni prestasi belajar siswa pada mata pelajaran IPS adalah sebesar 0,513. Jika dilihat dari arahnya, ternyata pengaruh antara variabel $\mathrm{x}$ terhadap variabel y menunjukan pengaruh yang positif. Untuk mengetahui kadar kuat lemahnya korelasi tersebut, dapat dilihat dari tabel korelasi berikut :

Kriteria Penafsiran Korelasi

\begin{tabular}{|c|c|}
\hline Interval Koefisien & Tingkat Hubungan \\
\hline $0,00-0,20$ & Korelasi rendah sekali \\
\hline $0,20-0,40$ & Korelasi rendah \\
\hline $0,40-0,70$ & Korelasi sedang \\
\hline $0,70-0,90$ & Korelasi tinggi \\
\hline $0,90-1,00$ & Korelasi sangat tinggi \\
\hline
\end{tabular}

Jika kita melihat tabel kriteria penafsiran korelasi di atas, ternyata nilai 0,51 terletak antara 0,40 - 0,70. Dengan demikian, tingkat korelasi antara kedua variabel yang diteliti penulis menunjukan bahwa antara variabel $\mathrm{x}$ dan variabel y terdapat korelasi Sedang. Artinya hubungan variabel $x$ (pengaruh sarana belajar) dengan variabel y (presatasi belajar siswa pada mata pelajaran IPS di kelas V) memiliki hubungan yang sedang.

Setelah mendapatkan nilai koefesien korelasi, kemudian menentukan tingkat pengaruh variabel $\mathrm{x}$ terhadap variabel $\mathrm{y}$ dengan rumus:

$$
\begin{aligned}
\mathrm{KD} & =\mathrm{r}^{2} \times 100 \\
& =0,51^{2} \times 100 \\
& =26
\end{aligned}
$$

Jadi variabel $\mathrm{x}$ (sarana belajar) memiliki tingkat pengaruh terhadap variabel y (prestasi belajar siswa pada mata pelajaran IPS) sebesar 26\%. Atau dapat dikatakan bahwa besarnya pengaruh sarana belajar terhadap prestasi siswa pada mata pelajaran IPS di kelas V SDN Tarikolot II Kabupaten Majalengka mencapai 26\%. Dengan demikian selebihnya $74 \%$ merupakan faktorfaktor lain yang dapat mempengaruhi peningkatan prestasi belajar siswa pada mata pelajaran IPS di kelas V SDN Tarikolot II, baik faktor internal maupun faktor eksternal.

\section{Uji Hipotesis}

Sebagaimana yang telah dikemukakan di muka, hipotesis yang dikemukakan dalam penelitian ini adalah "Ada pengaruh sarana belajar terhadap prestasi belajar siswa pada mata pelajaran IPS di kelas V SDN Tarikolot II Kabupaten Majalengka". Untuk menguji hipotesis dalam penelitian ini, penulis menggunakan rumus uji $t$ sebagai berikut:

$$
\begin{aligned}
& \mathrm{t}=\frac{r \sqrt{n-2}}{\sqrt{1-r^{2}}} \\
& \mathrm{t}=\frac{0,51 \sqrt{17-2}}{\sqrt{1-0,51}}
\end{aligned}
$$




$$
\begin{aligned}
& t=\frac{0,51 \sqrt{15}}{\sqrt{0,49}} \\
& t=\frac{0,51.3,87}{1,98} \\
& t=\frac{0,49}{0,70} \\
& t=2,82
\end{aligned}
$$

Bila menggunakan $t_{\text {tabel }}$ untuk kesalahan 5\% dan dk $=\mathrm{n}-2=17$, maka $\mathrm{t}_{\text {tabel }}=$ 1,74. Berdasarkan perhitungan di atas, dengan mengacu pada ketentuan jika $t_{\text {hitung }}$ $\left\langle\mathrm{t}_{\text {tabel }}=\right.$ Ho diterima dan $\mathrm{t}_{\text {hitung }}>\mathrm{t}_{\text {tabel }}=\mathrm{Ha}$ diterima. Dengan demikian dapat disimpulkan bahwa Hipotesis alternatif diterima dan Hipotesis nol ditolak, dengan kata lain hipotesis yang telah dikemukakan di awal bahwa, "Ada pengaruh sarana belajar terhadap prestasi belajar siswa pada mata pelajaran IPS di kelas V SDN Tarikolot II Kabupaten Majalengka”, telah terbukti kebenarannya.

\section{Interpretasi Data}

Berdasarkan hasil pengolahan data tentang kedua variabel yang diteliti, peneliti kemudian menganalisis data sebagai berikut:

a. Dari hasil uji normalitas data variabel $\mathrm{x}$ yaitu pengaruh sarana belajar, dengan menggunakan uji kolmogrov smirnov didapat nilai propability 0,200. Adapun dasar pengambilan keputusan adalah jika nilai sig. atau nilai probability $>0.05$ maka dikatakan distribusi data normal, dan jika nilai sig. atau nilai probability < 0.05 maka dikatakan distribusi data tersebut tidak normal. Berdasarkan hal tersebut maka sarana belajar berdistribusi normal, artinya bahwa data hasil sampel tersebut dapat diteliti dan refresentatif.

b. Dari hasil uji normalitas data variabel y yaitu prestasi belajar siswa pada mata pelajaran IPS di kelas V SDN Tarikolot II, dengan menggunakan uji kolmogrov smirnov didapat nilai propability 0,200. Adapun dasar pengambilan keputusan adalah jika nilai sig. atau nilai probability > 0.05 maka dikatakan distribusi data normal, dan jika nilai sig. atau nilai probablity < 0.05 maka dikatakan distribusi data tersebut tidak normal. Berdasarkan hal tersebut maka prestasi belajar siswa pada mata pelajaran IPS di kelas V SDN Tarikolot II berdistribusi normal, artinya bahwa data hasil sampel tersebut dapat diteliti dan refresentatif.

c. Berdasarkan uji korelasional antara variabel $\mathrm{x}$ dan $\mathrm{y}$ diperoleh data bahwa korelasi kedua variabel mencapai 0,51. Angka ini bila dilihat pada tabel korelasi berada pada interval $(0,40-0,70)$ dan mendapat penafsiran antara variabel $\mathrm{x}$ dan variabel y terdapat korelasi sedang.

d. Besarnya pengaruh variabel $\mathrm{x}$ (sarana belajar) terhadap variabel y (prestasi belajar) di kelas V SDN Tarikolot II mencapai 26\%. Maka 74\% merupakan faktor-faktor lain yang dapat mempengaruhi peningkatan prestasi belajar siswa, baik faktor internal maupun faktor eksternal.

\section{Kesimpulan dan Saran}

Berdasarkan hasil penelitian antara sarana belajar dengan prestasi belajar siswa pada mata pelajaran IPS di kelas V SDN Tarikolot II menunjukkan hubungan yang sedang. Hal tersebut terlihat dengan didapatnya nilai korelasi sebesar 0,51 . Nilai tersebut terletak antara 0,40 - 0,599 atau berkategori sedang. Sedangkan berdasarkan pengujian hipotesis, didapat nilai $t_{\text {hitung }}$ pada taraf nyata 0,05 berada di luar batas interval $t_{\text {tabel }}\left(\mathrm{t}_{\text {hitung }}>t_{\text {tabel }}=2,82>1,74\right.$ atau $-t_{\text {hitung }}<-t$ tabel $=-2,82<-1,74)$. Dengan demikian, hipotesis yang dikemukakan di awal yaitu "Ada pengaruh sarana belajar terhadap prestasi belajar siswa pada mata pelajaran IPS di kelas V SDN Tarikolot II Kabupaten Majalengka" dapat diterima dan telah terbukti kebenarannya.

Hasil penelitian ini di harapkan sebagai nilai tambah untuk meningkatkan ilmu pengetahuan dalam bidang pendidikan, guru harus kreatif dan terampil memberikan pengajaran dan memperjelas pesan dan informasi sehingga dapat memperlancar dan 
meningkatkan proses hasil belajar. Juga dapat menggairahkan perhatian anak sehingga dapat menimbulkan motivasi belajar siswa untuk berprestasi di kelas. Kemudian hasil penelitian ini diharapkan sebagai informasi dalam penyelenggaraan pendidikan yang lebih baik, sekolah dapat memfasilitasi sarana belajar secara langsung dalam menunjang proses belajar mengajar, seperti gedung, ruang kelas, meja, kursi, serta alat-alat media pengajaran.

\section{DAFTAR PUSTAKA}

Arikunto, S. (2006). Prosedur Penelitian Suatu Pendekatan Praktek. Jakarta: Rineka Cipta.

Arsyad, (2006). Media Pengajaran. Jakarta: PT. Raja Gravindo Persada.

Azwar, S. (2003). Tes presasi, Fungsi, dan pengembangan Pengukuran Prestasi Belajar. Yogyakarta: Pustaka Pelajar Offset.

Dimyati dan Mudjiono. (2009). Belajar dan Pembelajaran. Jakarta: Rineka Cipta.

Djamarah dan Aswan Zain. (2008). Strategi Belajar Mengajar. Jakarta: Rineka Cipta.

Djiwandono. (2008). Psikologi Pendidikan. Jakarta: PT Gramedia.

Faisal, Sanapiah. (2011). Format-Format Penelitian Sosial. Jakarta: Raja Grafindo Persada.

Jan Jonker, Bartjan J.W. Pennink, Sari Wahyuni.(2011). Metodologi Penelian Panduan Untuk Master di bidang Manajemen. Jakarta: Salemba Empat.

Mulyata. (2002). Manajemen Berbasis Sekolah. Bandung: Tarsito.
Roestiyah. (2001). Strategi Belajar Mengajar. Jakarta: Rineka Cipta.

Sanjaya, Wina. (2009). Strategi Pembelajaran Berorientasi Standar Proses Pendidikan. Jakarta: Kencana.

Sapriya, (2006). Pembelajaran dan Evaluasi Hasil belajar IPS Bandung: UPI PRESS.

Slameto. (2003). Belajar dan Faktor-Faktor yang Mempengaruhi. Jakarta: Rineka Cipta.

Sonatani, Uep dan Sambas. (2011). Desain Penelitian Kuantitatif. Bandung: Kerya.

Sugiyono. (2010). Metode Penelitian Kuantitatif Kualitatif. Bandung.

Suryabrata, Sumadi. (2004). Psikologi Pendidikan. Jakarta: Rajawali.

Udin S. Winataputra, dkk. (2003). Strategi Belajar Mengajar. Jakarta: Pusat Penerbitan Universitas Terbuka.

Wayan Nurkancana dan Sunartana. (2008). Evaluasi Hasil Belajar. Surabaya: Usaha Nasional.

Yasa, D. (2008). Aktivitas dan Prestasi Belajar. Jakarta: Depdiknas. 